\title{
EVALUASI FAKTOR HAMBATAN SAMPING PADA PENENTUAN KAPASITAS JALAN STUDI KASUS: JALAN JENDRAL SUDIRMAN JAKARTA
}

\author{
Yulia Rosaria Kunarti ${ }^{1}$ dan $^{\text {Najid }}{ }^{2}$ \\ ${ }^{1}$ Program Studi Sarjana Teknik Sipil, Universitas Tarumanagara, Jl. Letjen S. Parman No.1 Jakarta \\ Mariaelisabethyulia.ey@gmail.com \\ ${ }^{2}$ Program Studi Sarjana Teknik Sipil, Universitas Tarumanagara, Jl. Letjen S. Parman No.1 Jakarta \\ Najid2009@yahoo.com
}

Masuk: 14-07-2021, revisi: 22-11-2021, diterima untuk diterbitkan: 22-11-2021

\begin{abstract}
Technological developments and economic growth in the DKI Jakarta area have resulted in increased development in various fields, that the need for transportation facilities is increasing in the center of Jakarta, especially on Jalan Jendral Sudirman, traffic congestion is caused by an imbalance between increased use of vehicles and the growth of available road infrastructure, and the capacity of the existing road is smaller than the capacity of the planned road, all of which result in side obstacles. The purpose of this study was to analyze and evaluate side barriers in determining traffic capacity in various conditions and certain times, based on the 1997 MKJI guidelines. Calculating road capacity using secondary data from research that has been validated by previous researchers. in 2020 by Sarah Haryati, that data is obtained on Jalan Jendral Sudirman, Jakarta. In addition, we also use questionnaire data in the form of a google form to get the perception of these side barriers. The results obtained that the Jalan Jendral Sudirman Jakarta section is in the Very Low class in the morning, afternoon, and evening. For the next research, it is expected to specifically make a questionnaire to focus more on getting more valid data.
\end{abstract}

Keywords: Capacity; Volume; Factor Side Barriers; Jalan Jendral Sudirman Jakarta; MKJI 1997

\begin{abstract}
ABSTRAK
Perkembangan teknologi serta pertumbuhan ekonomi di wilayah DKI Jakarta mengakibatkan peningkatan pembangunan di berbagai bidang, sehingga kebutuhan sarana transportasi semakin meningkat pada pusat kota Jakarta terutama pada jalan Jendral Sudirman, kemacetan lalu lintas disebabkan oleh ketidak seimbangan antara peningkatan penggunaan kendaraan dan pertumbuhan prasarana jalan yang tersedia, serta kapasitas ruas jalan yang ada lebih kecil dari kapasitas jalan yang direncanakan, semua itu mengakibatkan adanya hambatan samping. Tujuan penelitian ini dilakukan untuk menganalisis dan juga mengevaluasi faktor hambatan samping pada penetuan kapasitas lalu lintas di berbagai macam kondisi dan waktu tertentu, dengan berdasarkan dari pedoman MKJI tahun 1997. Dengan menghitung kapasitas jalan menggunakan data sekunder dari penelitian yang sudah di validasi yang dilakukan oleh peneliti sebelumnya pada tahun 2020 oleh Sarah Haryati, didapatkan data-data pada jalan Jendral Sudirman, Jakarta. Selain itu kita juga menggunakan data kuesioner dalam bentuk google form untuk mendapatkan persepsi hambatan samping tersebut. Hasil yang didapatkan bahwa ruas Jalan Jendral Sudirman Jakarta terdapat dalam kelas Sangat Rendah pada waktu pagi hari, siang hari, dan sore hari. Untuk penelitian berikutnya, diharapkan secara khusus membuat kuesioner agar lebih fokus mendapatkan data yang lebih valid.
\end{abstract}

Kata kunci: Kapasitas; Volume; Faktor Hambatan Samping; Jalan Jendral Sudirman Jakarta; MKJI 1997

\section{PENDAHULUAN}

Pada umumnya perkembangan teknologi serta pertumbuhan ekonomi tepatnya di wilayah DKI Jakarta mengakibatkan peningkatan pembangunan di berbagai bidang, sehingga kebutuhan sarana transportasi semakin meningkat terutama pada pusat kota Jakarta, kemacetan lalu lintas disebabkan oleh ketidakseimbangan antara peningkatan penggunaan kendaraan dan pertumbuhan prasarana jalan yang tersedia, serta kapasitas ruas jalan yang ada lebih kecil dari kapasitas jalan yang direncanakan semua itu mengakibatkan adanya hambatan samping. Kapasitas jalan di tentukan oleh faktor kapasitas dasar, faktor lebar lajur, faktor hambatan samping, faktor proporsi 
lalu lintas per arah, dan faktor ukuran kota, yang secara teori ditentukan berdasarkan Manual Kapasitas Jalan Indonesia tahun 1997.

Pada pusat kota Jakarta tepatnya Jalan Jendral Sudirman adalah salah satu jalan utama kota Jakarta dan merupakan pusat bisnis atau biasa disebut Financial District (Poros Sudirman-Thamrin-Kuningan). Karena itu ruas jalan Jendral Sudirman merupakan salah satu ruas jalan yang cukup padat lalu lintasnya. Ruas jalan tersebut berada di kawasan CBD (Central Bussiness Distric). Hal ini mengakibatkan banyaknya kendaraan yang lewat atau berhenti pada ruas jalan tersebut, sehingga volume lalu lintasnya menjadi tinggi yang berarti volume lalu lintas tertinggi menunjukkan kapasitasnya.

Menurut MKJI 1997, hambatan samping adalah dampak terhadap kinerja lalu lintas yang berasal dari aktivitas samping segmen jalan. Hambatan samping sangat berpengaruh pada tingkat pelayanan disuatu ruas jalan. Pengaruh yang sangat jelas terlihat adalah berkurangnya kapasitas dan kinerja jalan, sehingga secara tidak langsung hambatan samping akan berpengaruh terhadap kecepatan kendaraan yang melalui jalan tersebut. Hambatan samping yang sangat mempengaruhi kapasitas jalan yaitu, pejalan kaki, kendaraan parkir maupun berhenti pada sisi jalan, kendaraan yang keluar dan masuk sisi jalan, dan kendaraan lambat.

Berdasarkan latar belakang, tujuan dari penelitian ini adalah menganalisis pengaruh hambatan samping akibat aktivitas tataguna lahan terhadap volume lalu lintas di jalan Jendral Sudirman Jakarta berdasarkan MKJI tahun 1997, menganalisis estimasi faktor hambatan samping berdasarkan estimasi kapasitas jalan aktual di jalan Jendral Sudirman Jakarta, mengevaluasi perhitungan kapasitas jalan berdasarkan MKJI 1997, serta persepsi pengguna jalan terhadap kondisi lalu lintas akibat faktor pengaruh hambatan samping.

\section{Hambatan samping}

Hambatan samping yaitu aktivitas samping jalan yang dapat menimbulkan konflik dan berpengaruh terhadap pergerakan arus lalu lintas serta menurunkan fungsi kinerja jalan. Tipe hambatan samping terbagi menjadi 4 yaitu:

1. Pejalan kaki

2. Kendaraan berhenti atau parkir

3. Kendaraan yang masuk dan keluar dari lahan samping jalan

4. Kendaraan lambat

Tingkat hambatan samping dikelompokkan dalam lima kelas, dari kelas rendah hingga kelas tinggi sebagai fungsi dari kejadian hambatan samping di sepanjang jalan yang diamati. Nilai kelas hambatan samping dapat dilihat pada Tabel 1.

Tabel 1. Nilai kelas hambatan samping

\begin{tabular}{cccc}
\hline $\begin{array}{c}\text { Kelas Hambatan } \\
\text { Samping (SCF) }\end{array}$ & Kode & $\begin{array}{c}\text { Jumlah Kejadian } / \\
\text { 200m / jam }\end{array}$ & Kondisi daerah \\
\hline Sangat Rendah & VL & $<100$ & $\begin{array}{c}\text { Daerah pemukiman; hampir tidak } \\
\text { ada kegiatan. }\end{array}$ \\
Rendah & L & $100-299$ & $\begin{array}{c}\text { Daerah pemukiman; berupa } \\
\text { angkutan umum dan sebagainya. } \\
\text { Daerah industri; beberapa toko di } \\
\text { sisi jalan. }\end{array}$ \\
Sedang & M & $300-499$ & $\begin{array}{c}\text { Daerah komersial; aktivitas sisi } \\
\text { jalan yang sangat tinggi. }\end{array}$ \\
Tinggi & H & $500-899$ & $\begin{array}{c}\text { Daerah komersial; aktivitas pasar } \\
\text { di samping jalan. }\end{array}$ \\
\hline
\end{tabular}

Sumber: Manual Kapasitas Jalan Indonesia 1997

Faktor-faktor yang mempengaruhi nilai kelas hambatan samping dengan frekuensi bobot kejadian per 200m dari segmen jalan yang diamati pada kedua sisi jalan seperti yang dijelaskan pada Tabel 2. 
Tabel 2. Penentuan tipe frekuensi kejadian hambatan samping

\begin{tabular}{lcc}
\hline \multicolumn{1}{c}{ Tipe kejadian hambatan samping } & Simbol & Faktor bobot \\
\hline Pejalan kaki & PED & 0,5 \\
Kendaraan parkir & PSV & 1,0 \\
Kendaraan masuk dan keluar sisi jalan & EEV & 0,7 \\
Kendaraan lambat & SMV & 0,4 \\
\hline
\end{tabular}

Sumber: Manual Kapasitas Jalan Indonesia 1997

\section{Kapasitas jalan}

Kapasitas jalan menurut Oglesby, C.H, 1993 didefinisikan sebagai arus kendaraan maksimum yang melewati satu titik pada jalan satu maupun kedua arah dalam periode waktu tertentu dan dibawah kondisi jalan dan lalu lintas yang umum. Kapasitasnya dinyatakan dalam kendaraan per jam atau smp per jam. Faktor-faktor yang mempengaruhi kaapsitas jalan antara lain kondisi geometri, kondisi lalu lintas dan kondisi lingkungan.

Penentuan kapasitas jalan, dapat diperoleh dari persamaan:

$$
\mathrm{C}=\mathrm{Co} \times \mathrm{FCw} \times \mathrm{FCsp} \times \mathrm{FCsf} \times \mathrm{FCcs}
$$

Dimana:

$\mathrm{C}=$ Kapasitas sesungguhnya $(\mathrm{smp} / \mathrm{jam})$

Co $=$ Kapasitas dasar (smp/jam)

$\mathrm{FCw}=$ Faktor penyesuaian akibat jalur lalu lintas

FCsp $=$ Faktor penyesuaian pemisah arah (jalan tak terbagi)

FCsf = Faktor penyesuaian hambatan samping dan bahu jalan

FCcs $=$ Faktor penyesuaian ukuran kota

Kapasitas dasar (Co) ditentukan berdasarkan tipe jalan sesuai dengan tabel 3.

Tabel 3. Kapasitas dasar (Co) jalan perkotaan

\begin{tabular}{ccc}
\hline & Kapasitas dasar (smp/jam) & Catatan \\
\hline Empat lajur tebagi atau jalan satu arah & 1650 & Perlajur \\
Empat lajur tak terbagi & 1500 & Perlajur \\
Dua lajur tak terbagi & 2900 & Total dua lajur \\
\hline
\end{tabular}

Sumber: Manual Kapasitas Jalan Indonesia 1997

\section{Ekivalen Mobil Penumpang (EMP)}

Dalam rekayasa lalu lintas, arus kendaraan yang bersifat campuran karena keragaman tipe kendaraan perlu diubah dalam suatu arus yang setara dengan acuan jenis kendaraan tertentu, dalam hal ini adalah mobil penumpang sehingga selanjutnya dinyatakan dalam satuan mobil penumpang. Dengan demikian arus dari berbagai tipe kendaraan harus diubah menjadi kendaraan mobil penumpang dengan menggunakan suatu nilai konversi yang disebut dengan ekivalensi mobil penumpang (Putranto, 2008). Nilai ekivalensi mobil penumpang disajikan pada tabel 4.

Tabel 4. Nilai ekivalensi jenis kendaraan

\begin{tabular}{ccc}
\hline No. & Jenisa Kendaraan & Satuan Mobil Penumpang \\
\hline 1 & Sepeda Motor & 0,3 \\
2 & Mobil Penumpang & 1 \\
3 & Truck Ringan & 1,2 \\
4 & Truck Sedang & 2,5 \\
5 & Bus & 1,2 \\
6 & Truck Berat & 3 \\
\hline
\end{tabular}

Sumber: Manual Kapasitas Jalan Indonesia 1997 


\section{Volume lalu lintas}

Volume lalu lintas adalah kendaraan yang dapat melewati ruas jalan tertentu dalam suatu waktu (hari, jam, menit). Satuan volume lalu lintas yang pada umumnya dapat diunakan berhubungan dengan suatu penelitian pada jumlah dan lebar lajur yaitu lalu lintas harian rata-rata, volume, dan kapasitas (Sukirman 1994).

Pengukuran volume kendaraan dengan metode pos pengamat tetap dilakukan dengan cara pengamat berada di pos pengamat yan gtelah ditentukan. Setiap orang dalam pos pengamat menghitung kendaraan yang keluar masuk dan mengklasifikasikan jenis kendaraan sesuai dengan kalsifikasi kendaraan yang diperlukan.

Pada dasarnya volume lalu lintas dapat dihitung dengan rumus sebagai berikut:

Dimana:

$$
Q=\frac{n}{t}
$$

$\mathrm{Q}=$ Volume lalu lintas (kendaraan/jam)

$\mathrm{n}=$ Jumlah kendaraan yang melintas (kendaraan)

$\mathrm{t}=$ Waktu (jam)

\section{METODE PENELITIAN}

Sistematika proses penelitian merupakan tahapan penelitian yang harus dilakukan secara beruntun agar tujuan penelitian dapat dicapai sesuai yang diharapkan. Tahapan penelitian yang harus dilakukan adalah sebagai berikut:

1. Menentukan tujuan penelitian, tujuan pustaka dan metodologi penelitian

2. Membuat formulir survei dan kuisioner

3. Melakukan pilot survei untuk kuisioner dan observasi lapangan

4. Melakukan revisi kuisioner

5. Melakukan pengumpulan data observasi dan kuisioner

6. Melakukan analisis data observasi dan kuisioner

7. Mecari hubungan antara hambatan samping dengan kecepatan dan volume lalu lintas dari data observasi

8. Menganalisis data persepsi terhadap hambatan samping

9. Kesimpulan dan saran

\section{Metode pengumpulan data}

Metode survei lapangan diperoleh dari benyebarkan dan mengumpulkan data kuisioner. Responden yang dituju untuk kuisioner ini adalah orang yang sering atau paling tidak seminggu satu sampai dua kali melalui jalan Jendral Sudirman Jakarta. Selain itu metode observasi lapangan dilakukan per 200meter pada wilayah penelitian selama 2 jam dan dicatat per 15 menit. Data-data yang diambil adalah volume lalu lintas yaitu sepeda motor, kendaraan ringan, dan kendaraan berat, kecepatan lalu lintas, dan jumlah hambatan samping.

\section{Metode analisis data}

Metode yang diggunakan untuk menganalisis data observasi adalah dengan menggunakan metode statistik yaitu metode korelasi pearson untuk mendapatkan korelasi antara volume lalu lintas dengan hambatan samping dan kecepatan lalu lintas dengan hambatan samping. Korelasi pearson dihitung dengan bantuan microsoft excel.

Kuisioiner diolah dengan mencari nilai rata-rata masing-masing hambatan samping sesuai dengan jawaban masingmasing responden dan dicari nilai dari masing-masing hambatan samping. Setelah itu nilai tersebut diurutkan sehingga menjadi urutan gangguan hambatan samping menurut responden.

\section{Kompilasi data}

Data-data yang didapat terdiri dari:

1. Volume lalu lintas

2. Kecepatan lalu lintas

3. Jumlah masing-masing hambatan samping

4. Data kuisioner 


\section{HASIL DAN PEMBAHASAN}

Jalan Jendral Sudirman merupakan tipe jalan yang memiliki 6 lajur 2 arah terbagi atau 6/2 D, dengan lebar jalan 18,5m, masing-masing jalur cepat memiliki lebar kurang lebih 3m, jalur busway terdapat di sisi kanan, jalur lambat di sisi kiri dan jalur pedestrial yang cukup luas lengkap dengan tanamannya. Kondisi badan jalan terbagi dengan adanya median jalan, jarak antara kereb dengan trotoar adalah kurang lebih $2 \mathrm{~m}$. Terdapat lebih kurang sekitar 10 juta jiwa penduduk di kota Jakarta berada di kawasan Jalan Jendral Sudirman, sebagai pusat kota Jakarta Jendral Sudirman ini merupakan kawasan perkantoran dan komersiil yang tentunya sangat berpengaruh terhadap lalu lintas.

\section{Karakteristik jalan}

Karakteristik jalan menurut MKJI akan mempengaruhi kapasitas dan kinerja jalan jika terdapat arus lalu lintas yang membebani jalan tersebut, Jalan Jendral Sudirman merupakan tipe jalan yang memiliki 6 lajur 2 arah terbagi atau $6 / 2 \mathrm{D}$, dengan lebar jalan 18,5m, masing-masing jalur cepat memiliki lebar kurang lebih 3m, jalur busway terdapat di sisi kanan, jalur lambat di sisi kiri dan jalur pedestrial yang cukup luas lengkap dengan tanamannya. Kondisi badan jalan terbagi dengan adanya median jalan, jarak antara kereb dengan trotoar adalah kurang lebih $2 \mathrm{~m}$. Data pada segmen jalan Jendral Sudirman dapat di lihat pada tabel 5, tabel 6, tabel 7, dan tabel 8.

Tabel 5 Data segmen Jalan Jendral Sudirman Jakarta

\begin{tabular}{ccc}
\hline No & Uraian & Keterangan \\
\hline 1 & Kota & Jakarta Pusat \\
2 & Ukuran Kota & Besar \\
3 & Tipe Daerah & Komersial dan Perkantoran \\
4 & Kelas Jalan & Arteri Sekunder \\
5 & Lebar Jalan & $2 \times(3 \times 3 \mathrm{~m})$ \\
6 & Jumlah Lajur & 3 Lajur per 1 arah \\
7 & Tipe Ruas Jalan & $6 / 2 \mathrm{D}$ \\
8 & Lebar Trotoar & $2 \mathrm{~m}$ \\
9 & Lebar Median & $1 \mathrm{~m}$ \\
10 & Lebar Bahu Jalan & $0,5 \mathrm{~m}$ \\
\hline
\end{tabular}

Tabel 6 Data kendaraan dan kecepatan di ruas Jalan Jendral Sudirman Jakarta (Pagi Hari)

\begin{tabular}{|c|c|c|c|c|c|c|c|}
\hline \multirow{2}{*}{ Waktu } & \multirow{2}{*}{$\begin{array}{c}\text { Jarak } \\
(\mathrm{m})\end{array}$} & \multicolumn{2}{|c|}{ Motor } & \multicolumn{2}{|l|}{ Mobil } & \multirow{2}{*}{$\begin{array}{r}\text { Bus/Truk } \\
\text { Jumlah }\end{array}$} & \multirow{2}{*}{$\begin{array}{c}\text { Kec rat } \\
\bar{S}\end{array}$} \\
\hline & & Jumlah & $\mathrm{T}(\mathrm{s})$ & Jumlah & $\mathrm{T}(\mathrm{s})$ & & \\
\hline $06.00-06.15$ & 200 & 2910 & 18 & 1698 & 20 & 18 & 38,000 \\
\hline $06.15-06.30$ & 200 & 2865 & 18 & 1437 & 21 & 21 & 37,143 \\
\hline $06.30-06.45$ & 200 & 2955 & 18 & 1653 & 21 & 24 & 37,143 \\
\hline $06.45-07.00$ & 200 & 2802 & 19 & 1797 & 22 & 15 & 35,311 \\
\hline $07.00-07.15$ & 200 & 2913 & 19 & 1704 & 21 & 15 & 36,090 \\
\hline $07.15-07.30$ & 200 & 2853 & 18 & 1674 & 21 & 21 & 37,143 \\
\hline $07.30-07.45$ & 200 & 2919 & 19 & 1587 & 20 & 18 & 36,947 \\
\hline $07.45-08.00$ & 200 & 2760 & 18 & 1590 & 20 & 18 & 38,000 \\
\hline
\end{tabular}


Tabel 7 Data kendaraan dan kecepatan di ruas Jalan Jendral Sudirman Jakarta (Siang Hari)

\begin{tabular}{cccccccc}
\hline \multirow{2}{*}{ Waktu } & Jarak & \multicolumn{2}{c}{ Motor } & \multicolumn{2}{c}{ Mobil } & Bus/Truk & \multirow{2}{*}{ Kec rat } \\
\cline { 3 - 6 } & $(\mathrm{m})$ & Jumlah & $\mathrm{T}(\mathrm{s})$ & Jumlah & $\mathrm{T}(\mathrm{s})$ & Jumlah & $\bar{S}$ \\
\hline $12.00-12.15$ & 200 & 3087 & 18 & 1275 & 22 & 15 & 36,364 \\
$12.15-12.30$ & 200 & 3261 & 18 & 1467 & 22 & 6 & 36,364 \\
$12.30-12.45$ & 200 & 3069 & 19 & 1671 & 23 & 15 & 34,600 \\
$12.45-13.00$ & 200 & 3009 & 20 & 1578 & 24 & 6 & 33,000 \\
$13.00-13.15$ & 200 & 3381 & 19 & 1494 & 23 & 6 & 34,600 \\
$13.15-13.30$ & 200 & 3603 & 20 & 1485 & 23 & 15 & 33,652 \\
$13.30-13.45$ & 200 & 3366 & 19 & 1728 & 24 & 6 & 33,947 \\
$13.45-14.00$ & 200 & 3450 & 18 & 1551 & 22 & 15 & 36,364 \\
\hline
\end{tabular}

Tabel 8 Data kendaraan dan kecepatan di ruas Jalan Jendral Sudirman Jakarta (Sore Hari)

\begin{tabular}{cccccccc}
\hline \multirow{2}{*}{ Waktu } & Jarak & \multicolumn{2}{c}{ Motor } & \multicolumn{2}{c}{ Mobil } & Bus/Truk & Kec rat \\
\cline { 3 - 6 } & $(\mathrm{m})$ & Jumlah & $\mathrm{T}(\mathrm{s})$ & Jumlah & $\mathrm{T}(\mathrm{s})$ & Jumlah & $\bar{S}$ \\
\hline $17.00-17.15$ & 200 & 2790 & 18 & 1497 & 25 & 24 & 34,400 \\
$17.15-17.30$ & 200 & 2829 & 17 & 1617 & 25 & 6 & 35,576 \\
$17.30-17.45$ & 200 & 2745 & 17 & 1587 & 26 & 9 & 35,023 \\
$17.45-18.00$ & 200 & 2721 & 20 & 1626 & 29 & 3 & 30,414 \\
$18.00-18.15$ & 200 & 2808 & 20 & 1593 & 28 & 6 & 30,857 \\
$18.15-18.30$ & 200 & 2928 & 18 & 1800 & 28 & 3 & 32,857 \\
$18.30-18.45$ & 200 & 3003 & 18 & 1602 & 25 & 9 & 34,400 \\
$18.45-19.00$ & 200 & 2841 & 20 & 1719 & 26 & 18 & 31,846 \\
\hline
\end{tabular}

Volume lalu lintas diperoleh dari data sebelumnya dengan hasil pencatatan jumlah arus lalu lintas berdasarkan jenis kendaraan yang meliputi kendaraan ringan Light Vehicle (LV), kendaraan berat Heavy Vehicle (HV), dan sepeda motor Motorcycle (MC). Data jumlah kendaraan perjam disesuaikan satuan mobil penumpang. Hasil analisis volume dijasikan pada tabel 9 untuk kondisi pagi hari, kondisi siang hari pada tabel 10, dan untuk kondisi sore hari pada tabel 11 .

Tabel 9 Analisis volume dan kapasitas di ruas Jendral Sudirman Jakarta

(Pagi Hari)

\begin{tabular}{|c|c|c|c|c|c|c|c|c|c|}
\hline \multirow{2}{*}{ Waktu } & \multirow{2}{*}{$\begin{array}{c}\text { Jarak } \\
(\mathrm{m})\end{array}$} & \multicolumn{2}{|c|}{ Motor } & \multicolumn{2}{|l|}{ Mobil } & Bus/Truk & \multirow{2}{*}{ V (Vol) } & \multirow{2}{*}{$\begin{array}{c}\mathrm{C} \\
\text { (Kapasitas) }\end{array}$} & \multirow{2}{*}{$\frac{V}{C}$} \\
\hline & & $\Sigma$ (smp) & $\mathrm{T}(\mathrm{s})$ & $\overline{\Sigma(\mathrm{smp})}$ & $\mathrm{T}(\mathrm{s})$ & $\overline{\Sigma(\mathrm{smp})}$ & & & \\
\hline $06.00-07.00$ & 200 & 3459,6 & 73 & 6585 & 84 & 93,6 & 10138,2 & 4736,16 & 2,141 \\
\hline $06.15-07.15$ & 200 & 3460,5 & 74 & 6591 & 85 & 90 & 10141,5 & 4736,16 & 2,141 \\
\hline $06.30-07.30$ & 200 & 3456,9 & 74 & 6828 & 85 & 90 & 10374,9 & 4736,16 & 2,191 \\
\hline $06.45-07.45$ & 200 & 3446,1 & 75 & 6762 & 84 & 82,8 & 10290,9 & 4736,16 & 2,173 \\
\hline $07.00-08.00$ & 200 & 3433,5 & 74 & 6555 & 82 & 86,4 & 10074,9 & 4736,16 & 2,127 \\
\hline
\end{tabular}


Tabel 10 Analisis volume dan kapasitas di ruas Jendral Sudirman Jakarta (Siang Hari)

\begin{tabular}{|c|c|c|c|c|c|c|c|c|c|}
\hline \multirow{2}{*}{ Waktu } & \multirow{2}{*}{$\begin{array}{l}\text { Jarak } \\
(\mathrm{m})\end{array}$} & \multicolumn{2}{|c|}{ Motor } & \multicolumn{2}{|l|}{ Mobil } & Bus/Truk & \multirow{2}{*}{ V (Vol) } & \multirow{2}{*}{$\begin{array}{c}\mathrm{C} \\
\text { (Kapasitas) }\end{array}$} & \multirow{2}{*}{$\frac{V}{C}$} \\
\hline & & $\Sigma(\mathrm{smp})$ & $\mathrm{T}(\mathrm{s})$ & $\Sigma(\mathrm{smp})$ & $\mathrm{T}(\mathrm{s})$ & $\Sigma(\mathrm{smp})$ & & & \\
\hline $12.00-13.00$ & 200 & 3727,8 & 75 & 5991 & 91 & 50,4 & 9769,2 & 4736,16 & 2,063 \\
\hline $12.15-13.15$ & 200 & 3816,0 & 76 & 6210 & 92 & 39,6 & 10065,6 & 4736,16 & 2,125 \\
\hline $12.30-13.30$ & 200 & 3918,6 & 78 & 6228 & 93 & 50,4 & 10197,0 & 4736,16 & 2,153 \\
\hline $12.45-13.45$ & 200 & 4007,7 & 78 & 6285 & 94 & 39,6 & 10332,3 & 4736,16 & 2,182 \\
\hline $13.00-14.00$ & 200 & 4140,0 & 76 & 6258 & 92 & 50,4 & 10448,4 & 4736,16 & 2,206 \\
\hline
\end{tabular}

Tabel 11 Analisis volume dan kapasitas di ruas Jendral Sudirman Jakarta (Sore Hari)

\begin{tabular}{|c|c|c|c|c|c|c|c|c|c|}
\hline \multirow{2}{*}{ Waktu } & \multirow{2}{*}{$\begin{array}{c}\text { Jarak } \\
(\mathrm{m})\end{array}$} & \multicolumn{2}{|c|}{ Motor } & \multicolumn{2}{|l|}{ Mobil } & \multirow{2}{*}{$\begin{aligned} \text { Bus/Truk } \\
\Sigma(\text { smp) }\end{aligned}$} & \multirow{2}{*}{ V (Vol) } & \multirow{2}{*}{$\begin{array}{c}\mathrm{C} \\
\text { (Kapasitas) }\end{array}$} & \multirow{2}{*}{$\frac{V}{C}$} \\
\hline & & $\overline{\Sigma(\mathrm{smp})}$ & $\mathrm{T}(\mathrm{s})$ & $\Sigma(\mathrm{smp})$ & $\mathrm{T}(\mathrm{s})$ & & & & \\
\hline $17.00-18.00$ & 200 & 3325,5 & 72 & 6327 & 105 & 50,4 & 9702,9 & 4736,16 & 2,049 \\
\hline $17.15-18.15$ & 200 & 3330,9 & 74 & 6423 & 108 & 28,8 & 9782,7 & 4736,16 & 2,066 \\
\hline $17.30-18.30$ & 200 & 3360,6 & 75 & 6606 & 111 & 25,2 & 9991,8 & 4736,16 & 2,110 \\
\hline $17.45-18.45$ & 200 & 3438,0 & 76 & 6621 & 110 & 25,2 & 10084,2 & 4736,16 & 2,129 \\
\hline $18.00-19.00$ & 200 & 3474,0 & 76 & 6714 & 107 & 43,2 & 10231,2 & 4736,16 & 2,160 \\
\hline
\end{tabular}

\section{Analisis ekivalen mobil penumpang}

Volume lalu lintas diperoleh dari data sebelumnya dengan hasil pencatatan jumlah arus lalu lintas berdasarkan jenis kendaraan yang meliputi kendaraan ringan Light Vehicle (LV), kendaraan berat Heavy Vehicle (HV), dan sepeda motor Motorcycle (MC). Data jumlah kendaraan perjam disesuaikan satuan mobil penumpang.

Analisis volume lalu lintas pada pukul $13.00-14.00$

$$
\begin{aligned}
\text { Jumlah Sepeda Motor (MC) } & =13800 \mathrm{kend} \\
& =13800 \times 0,3 \\
& =4140 \mathrm{smp} \\
\text { Jumlah Kendaraan Ringan (LV) } & =6258 \mathrm{kend} \\
& =6258 \times 1,0 \\
& =6258 \mathrm{smp} \\
\text { Jumlah Kendaraan Berat (HV) } & =42 \mathrm{kend} \\
& =42 \times 1,2 \\
& =50,4 \mathrm{smp} \\
\text { Total Volume (smp) } & =10448.4 \mathrm{smp}
\end{aligned}
$$

\section{Analisis hambatan samping}

Hambatan samping yang terjadi pada jalan tersebut yaitu kendaraan yang keluar masuk atau akses sisi kiri dan kanan jalan serta kendaraan parkir dan berhenti sepanjang 200meter pada pagi hari pukul 06.00 - 08.00 siang hari pada pukul 12.00 - 14.00, dan sore hari pada pukul 17.00 - 19.00. Data yang didapat kemudian dikalikan faktor hambatan sampingnya. Untuk kendaaran yang keluar masuk dikalikan 0,7, kendaraan yang parkir atau berhenti dikalikan 1, lalu hasil frekuensi bobot tersebut dilihat dalam MKJI 1997 untuk menentukan kelas hambatan samping tersebut. 
Banyaknya aktivitas hambatan samping pada jalan perkotaan dikategorikan ke dalam beberapa kelas yaitu Very Low (sangat rendah), Low (rendah), Medium (sedang), High (tinggi), Very High (sangat tinggi).

Berikut ini adalah hasil survei analisis hambatan samping pada pagi, siang, dan sore yang disajikan kedalam bentuk tabel 12.

Tabel 12. Analisis hambatan samping dan kapasitas Jalan Jendral Sudirman

\begin{tabular}{ccccc}
\hline Waktu & $\begin{array}{c}\text { Akses keluar } \\
\text { masuk sisi jalan }\end{array}$ & $\begin{array}{c}\text { Kendaraan parkir } \\
\text { dan berhenti }\end{array}$ & $\begin{array}{c}\text { Kelas } \\
\text { hambatan }\end{array}$ & $\begin{array}{c}\text { Frekuensi } \\
\text { bobot }\end{array}$ \\
\hline $06.00-08.00$ & 30 & 21 & VL & 42 \\
$12.00-14.00$ & 41 & 25 & VL & 53,7 \\
$17.00-19.00$ & 27 & 13 & VL & 31,9 \\
\hline
\end{tabular}

Dari hasil analisis hambatan samping di ruas jalan Jendral Sudirman didapatkan hasil bahwa kelas hambatan samping VL (Very Low) terjadi baik pada waktu pagi hari, siang hari, maupun sore hari.

\section{Kapasitas}

Berdasarkan hasil analisis hambatan samping yang telah dilakukan nilai faktor penyesuaian hambatan samping FCsf sangat berpengaruh nilainya terhadap kapasitas jalan. Karena hasil kapasitas berdasarkan MKJI 1997 pada jalan Jendral Sudirman Jakarta ini kurang memenuhi sehingga dicari nilai FCsf model untuk jalan Jendral Sudirman dengan menggunakan data penelitian analisis volume dan kecepatan serta analisis hambatan samping yang telah dilakukan sertaserta memperhatikan beberapa faktor penyelesaian lainnya seperti jalan Jendral Sudirman Jakarta ini memiliki tipe jalan 3 lajur satu arah sehingga nilai Co adalah 1650, lebar badan jalan Jendral Sudirman terdiri dari 6 lajur 2 arah dan memiliki lebar lajur 3meter sehingga $\mathrm{FCw}$ adalah 0,92, jalan menggunakan median sehingga kondisi badan jalan terbagi maka nilai FCsp adalah 1, dan jumlah penduduk kota Jakarta tahun 2020 adalah 10,56 juta penduduk jiwa, sehingga FCcs adalah 1,04. sehingga didapat hasil perhitungan nilai estimasi kapasitas yang disajikan pada tabel 13 .

Tabel 13. Volume dan $\frac{V}{C}$

\begin{tabular}{cccc}
\hline Waktu & V (Vol) & C (Kapasitas) & $\frac{V}{C}$ \\
\hline $06.00-07.00$ & 10138,2 & 4736,16 & 2,141 \\
$06.15-07.15$ & 10141,5 & 4736,16 & 2,141 \\
$06.30-07.30$ & 10374,9 & 4736,16 & 2,191 \\
$06.45-07.45$ & 10290,9 & 4736,16 & 2,173 \\
$07.00-08.00$ & 10074,9 & 4736,16 & 2,127 \\
$12.00-13.00$ & 9769,2 & 4736,16 & 2,063 \\
$12.15-13.15$ & 10065,6 & 4736,16 & 2,125 \\
$12.30-13.30$ & 10197,0 & 4736,16 & 2,153 \\
$12.45-13.45$ & 10332,3 & 4736,16 & 2,182 \\
$13.00-14.00$ & 10448,4 & 4736,16 & 2,206 \\
$17.00-18.00$ & 9702,9 & 4736,16 & 2,049 \\
$17.15-18.15$ & 9782,7 & 4736,16 & 2,066 \\
$17.30-18.30$ & 9991,8 & 4736,16 & 2,110 \\
$17.45-18.45$ & 10084,2 & 4736,16 & 2,129 \\
$18.00-19.00$ & 10231,2 & 4736,16 & 2,160 \\
\hline
\end{tabular}




\section{Estimasi kapasitas}

Estimasi kapasitas berdasarkan volume tersibuk dapat dilihat pada tabel 14 berikut ini

Tabel 5. Estimasi kapasitas dan kondisi hambatan samping

\begin{tabular}{ccccc}
\hline & & Estimasi & \multicolumn{2}{c}{ Hambatan Samping } \\
\cline { 4 - 5 } No & Waktu & Kapasitas & $\begin{array}{c}\text { Kendaraan } \\
\text { Berhenti }\end{array}$ & Akses Sisi Jalan \\
\hline 1 & $12.30-13.30$ & 10197,0 & 41 & 25 \\
2 & $12.45-13.45$ & 10332,3 & 41 & 25 \\
3 & $13.00-14.00$ & 10448,4 & 41 & 25 \\
\hline
\end{tabular}

\section{Analisis faktor hambatan samping}

Hambatan samping merupakan dampak terhadap kinerja lalu lintas dari aktifitas samping segmen jalan, seperti pejalan kaki, kendaraan parkir/berhenti, kendaraan keluar masuk dari sisi jalan, dan kendaraan lambat. Berdasarkan MKJI kapasitas jalan lebih besar dibandingkan dengan volume lalu lintas di jam sibuk sehingga di dilakukan perhitungan kapasitas model, supaya kapasitas dapat memenuhi syarat lalu lintas yang lebih ideal.

Dalam perhitungan hambatan samping, langkah-langkah perhitungannya adalah menentukan nilai-nilai yang dijadikan dasar perhitugan hambatan samping yaitu kapasitas dasar dan beberapa faktor penyelesaian.

$\mathrm{Co}^{+}=3 \times 1650 \times \mathrm{FCW} \times \mathrm{FCsp} \times \mathrm{FCsf} \times \mathrm{FCcs}$

$\mathrm{Co}^{+}=3 \times 1650 \times 0,92 \times 1 \times \mathrm{FCsf} \times 1,04=4736 \mathrm{smp} / \mathrm{jam}$

Analisis hambatan samping pada ruas jalan pada Jalan Jendral Sudirman Jakarta adalah sebagai berikut:

Analisis FCsf kondisi waktu (12.30 - 13.30)

Est. $\mathrm{C}=\mathrm{Co}^{+} \times \mathrm{FCsf}$

$10197,0=4736 \times$ FCsf

FCsf $=2,153$ (tidak terakomodasikan)

Analisis FCsf kondisi waktu (12.45 - 13.45)

Est. $\mathrm{C}=\mathrm{Co}^{+} \times \mathrm{FCsf}$

$10332,3=4736 \times$ FCsf

FCsf $=2,182$ (tidak terakomodasikan)

Analisis FCsf kondisi waktu (13.00 - 14.00)

Est.C $=\mathrm{Co}^{+} \times \mathrm{FCsf}$

$10448,4=4736 \times$ FCsf

FCsf = 2,206 (tidak terakomodasikan)

\section{Analisis data kuisioner}

Dari data yang diperoleh berdasarkan uji kuisioner secara online di social media yang dibuat dengan menggunakan Google Form didapatkan data kuisioner sebanyak 100 responden yang adalah seluruh warga atau siapapun yang sering atau setidaknya seminggu satu hingga dua kali melalui jalan yang sedang diteliti yaitu Jendral Sudirman Jakarta. Hasil data kuisioner disajikan pada tabel 15 dan tabel 16. 
Tabel 15. Data pengaruh hambtana samping di Jalan Jendral Sudirman Jakarta kondisi macet

\begin{tabular}{cccccc}
\hline \multirow{2}{*}{ No } & \multirow{2}{*}{ Jenis Hambatan Samping } & \multicolumn{4}{c}{ Kondisi Macet } \\
\cline { 3 - 6 } & & 1 & 2 & 3 & 4 \\
\hline 1 & Kendaraan berhenti atau parkir disisi jalan & 58 & 29 & 13 & 0 \\
2 & Kendaraan dari akses sisi jalan & 18 & 42 & 35 & 5 \\
3 & Pejalan kaki di badan jalan & 21 & 22 & 23 & 34 \\
4 & Kendaraan tidak bermotor & 12 & 22 & 39 & 27 \\
\hline
\end{tabular}

Keterangan:

1 = Sangat Mengganggu

$2=$ Mengganggu

3 = Cukup Mengganggu

$4=$ Kurang Mengganggu

Tabel 16. Data pengaruh hambatan samping di Jalan Jendral Sudirman Jakarta kondisi tidak macet

\begin{tabular}{cccccc}
\hline \multirow{2}{*}{ No } & \multirow{2}{*}{ Jenis Hambatan Samping } & \multicolumn{3}{c}{ Kondisi Tidak Macet } \\
\cline { 3 - 6 } & & 1 & 2 & 3 & 4 \\
\hline 1 & Kendaraan berhenti atau parkir disisi jalan & 28 & 28 & 27 & 17 \\
2 & Kendaraan dari akses sisi jalan & 11 & 28 & 35 & 26 \\
3 & Pejalan kaki di badan jalan & 12 & 19 & 23 & 46 \\
4 & Kendaraan tidak bermotor & 7 & 19 & 34 & 40 \\
\hline
\end{tabular}

Keterangan:

1 = Sangat Mengganggu

2 = Mengganggu

3 = Cukup Mengganggu

4 = Kurang Mengganggu

Dari hasil kuesioner didapatkan bahwa jenis hambatan samping, kendaraan berhenti atau parkir di sisi jalan merupakan jenis hambatan samping yang paling mengganggu dan pejalan kaki di badan jalan sebagai urutan kedua yang mengganggu aktifitas jalan menurut responden dalam kuesioner tersebut. Urutan bobot gangguan disajikan pada tabel 17 .

Tabel 17. Analisis data kuisioner hambatan samping dengan bobot gangguan

\begin{tabular}{|c|c|c|c|c|c|}
\hline No & $\begin{array}{l}\text { Jenis Hambatan } \\
\text { Samping }\end{array}$ & $\begin{array}{c}\text { Data Kondisi } \\
\text { Macet }\end{array}$ & $\begin{array}{l}\text { Urutan Bobot } \\
\text { Gangguan }\end{array}$ & $\begin{array}{l}\text { Data kondisi } \\
\text { Tidak Macet }\end{array}$ & $\begin{array}{c}\text { Urutan Bobot } \\
\text { Gangguan }\end{array}$ \\
\hline 1 & $\begin{array}{l}\text { Kendaraan berhenti atau } \\
\text { parkir disisi jalan }\end{array}$ & 155 & 1 & 233 & 1 \\
\hline 2 & $\begin{array}{l}\text { Kendaraan dari akses } \\
\text { sisi jalan }\end{array}$ & 245 & 2 & 276 & 2 \\
\hline 3 & $\begin{array}{c}\text { Pejalan kaki di badan } \\
\text { jalan }\end{array}$ & 270 & 3 & 303 & 3 \\
\hline 4 & $\begin{array}{c}\text { Kendaraan tidak } \\
\text { bermotor }\end{array}$ & 281 & 4 & 307 & 4 \\
\hline
\end{tabular}

Berdasarkan hasil observasi yang dilakukan oleh penelitian sebelumnya juga menunjukkan bahwa hambatan samping yang terjadi pada ruas Jalan Jendral Sudirman Jakarta menunjukkan kendaraan berhenti dan kendaraan dari akses sisi jalan yang paling berpengaruh pada hambatan samping yang terjadi. 


\section{KESIMPULAN DAN SARAN}

\section{Kesimpulan}

Berdasarkan hasil survei lalu lintas dan hambatan samping, tidak ada hubungan kuat antara hambatan samping dan volume lalu lintas.

Berdasarkan hasil perhitungan FCsf berdasarkan volume lalu lintas jam sibuk terlihat faktor hambatan samping sangat rendah.

Kondisi volume lalu lintas jam sibuk jauh diatas kapasitas, berdasarkan MKJI 1997, dengan volume lalu lintas jam sibuk didapat FCsf jauh diatas maksimum pada table C-4:1 pada MKJI, sehingga patut diduga bahwa untuk merevisi MKJI perlu merevisi faktor yang mempunyai faktor pengaruh besar.

Berdasarkan hasil analisis kuisioner data hambatan samping pada kondisi macet dengan kondisi tidak macet memiliki urutan bobot gangguan yang sama dengan MKJI 1997.

Melihat hasil analisis koefisien faktor hambatan samping menunjukkan perbaikan revisi MKJI khususnya untuk analisis kapasitas mengindikasikan perlunya revisi kapasitas dasar khususnya kapasitas dasar untuk jalan tipe 6/2D.

\section{Saran}

Dibutuhkan manajemen lalu lintas yang lebih tepat untuk mengurangi hambatan samping, sehingga dapat meningkatkan nilai kapasitas jalan.

Penelitian yang sama perlu dilakukan pada ruas-ruas jalan yang lainnya yang memilikki nilai hambatan samping dan kepadatan lalu lintas yang berbeda.

\section{DAFTAR PUSTAKA}

Haryati, S., \& Najid. (2020). Analisis Kapasitas dan Kinerja Lalu Lintas Pada Ruas Jalan Jendral Sudirman. Jurnal Mitra Teknik Sipil, 4(1), 95-108.

MKJI. (1997). Manual Kapasitas Jalan Indonesia (MKJI). Direktorat Jendral Bina Marga Departemen Pekerjaan Umum, Jakarta.

Oglesby, C. H. (1993). Teknik Jalan Raya. Jakarta: Erlangga.

Putranto, L. S. (2008). Rekayasa Lalu Lintas. Jakarta: Indeks.

Sukirman, S. (1994). Dasar-Dasar Perencanaan Geometrik Jalan Raya. Bandung: Nova. 
